WOMEN OF THE RIGHT 



\section{WOMEN OF THE RIGHT}

Comparisons and Interplay Across Borders 


\section{Library of Congress Cataloging-in-Publication Data}

Women of the right : comparisons and interplay across borders / edited by Kathleen M. Blee and Sandra McGee Deutsch.

p. $\mathrm{cm}$.

Includes bibliographical references and index.

Summary: "An interdisciplinary collection of essays examining the role of women in right-wing political activism around the world, from the Afrikaner movement in South Africa in the early twentieth century to the supporters of Sarah Palin in the United States"-Provided by publisher.

ISBN 978-0-27I-05215-I (cloth : alk. paper)

I. Women-Political activity-Cross-cultural studies.

2. Women political activists-Cross-cultural studies.

3. Women conservatives_Cross-cultural studies.

I. Blee, Kathleen M.

II. Deutsch, Sandra McGee, I950- .

HQ1236.W63855 2012

$320.52082-\mathrm{dc} 23$

2011031329

Copyright (C) 20I2 The Pennsylvania State University All rights reserved

Printed in the United States of America

Published by The Pennsylvania State University Press,

University Park, PA I6802-1003

The Pennsylvania State University Press is a member of the Association of American University Presses.

It is the policy of The Pennsylvania State University Press to use acid-free paper. Publications on uncoated stock satisfy the minimum requirements of American National Standard for Information Sciences-Permanence of Paper for Printed Library Material, ANSI Z39.48-I992.

This book is printed on Natures Natural, which contains $50 \%$ post-consumer waste. 